\title{
Dachstein Limestone from Krn in Julian Alps (Slovenia)
}

\section{Razvoj dachsteinskega apnenca na Krnu v Julijskih Alpah}

\author{
Bojan Ogorelec \\ Geološki zavod Ljubljana \\ Inštitut za geologijo, geotehniko in geofiziko \\ Dimičeva 14, 1001 Ljubljana, Slovenija
}

\section{Stanko Buser}

Univerza v Ljubljani, Naravoslovnotehniška fakulteta

Oddelek za geologijo, Aškerčeva 2, 1000 Ljubljana, Slovenija

\author{
A stari moj Krn, \\ ki seval okrog milijone je krat \\ o soncu ko zlat, \\ a v zimi neštetokrat bil je srebrn, \\ in vedno je gledal brezčutno $\mathrm{k}$ nam dol, \\ sè srcem brez čuta je srečen, \\ saj on je pač večen, \\ (Simon Gregorčič, Iz predsmrtnic, 9)
}

\author{
And my old Krn \\ that shone many million times \\ in sun like a golden coin, \\ while in winter he was silvery so many times, \\ and always he looked merciless down on us, \\ happy in his impassive heart, \\ eternal as he is. \\ (Simon Gregorčič, from Songs before death, 9 \\ Slovenian poet (1844-1906), \\ born in the village Vrsno by $\mathrm{Krn}$ )
}

Key words: Dachstein limestone, Upper Triassic, sedimentology, paleogeography, Julian Alps

Ključne besede: dachsteinski apnenec, zgornji trias, sedimentologija, paleogeografija, Julijske Alpe

\begin{abstract}
The Dachstein limestone from Krn is characterized by Lofer development. The section encompasses 30 cyclothems on average $3-4$ metres thick. Intra- and supratidal environment of deposition is evident by stromatolites, loferite and tempestite breccias. They were all locally affected by early diagenetic dolomitization. Biomicritic limestone with several horizons of megalodont clams was deposited in shallow and restricted shelf. Basal members A of the Lofer cyclothem are developed only exceptionally. Solution cavities are fairly common, being infilled by sparry calcite and insoluble rich red limestone.

The limestone was deposited on the Julian carbonate platform near its passage part to the southerly lying Slovenian basin. In this part reigned specific circumstances that resulted into formation of very numerous corrosion vugs; they are filled in their central parts by variegated marly clay. Interesting are frequent tem-
\end{abstract}


pestite layers. Their origin is explained by synsedimentary tectonic processes that caused fracturing and slumping in unconsolidated limestone beds.

\section{Kratka vsebina}

Dachsteinski apnenec na Krnu kaže vse značilnosti loferskega razvoja. S profilom je bilo zajetih 30 ciklotem, ki so v povprečju debele 3 do 4 metre. V med- in nadplimskem okolju so nastajale stromatolitne in loferitne plasti ter tempestitit ("nadplimski konglomerat"); vse je ponekod zajela zgodnjediagenetska dolomitizacija. V plitvem in mirnem šelfu se je odlagal biomikritni apnenec z več horizonti megalodontidnih školjk. Bazalni členi loferske cikloteme A so razviti le izjemoma. Pogoste so korozijske votline, zapolnjene s pasovitim sparitnim kalcitom in residualno karbonatno glino.

Apnenec je nastal na Julijski karbonatni platformi blizu pregibnega dela z južneje ležečim Slovenskim bazenom. V tem delu so bile specifične okoliščine, ki so povzročile nastanek izredno številnih korozijskih votlin; le-te v središčnem delu zapolnjuje različno obarvana laporna glina. Zanimive so pogostne plasti tempestitov. Njihov nastanek razlagava s sinsedimentarnimi tektonskimi procesi, ki so povzročili razlamljanje in zdrsnitve še nekonsolidiranih plasti apnenca.

\section{Introduction}

When approaching the middle Soča River area, the eye is caught by vast mountainous massifs of the Julian Alps among which is especially dominant the mighty summit of Krn (fig. 1). These massifs are prevailingly built of the more than 1000 meters thick sequence of light thick bedded limestone that is known in the geological literature as the Dachstein limestone.

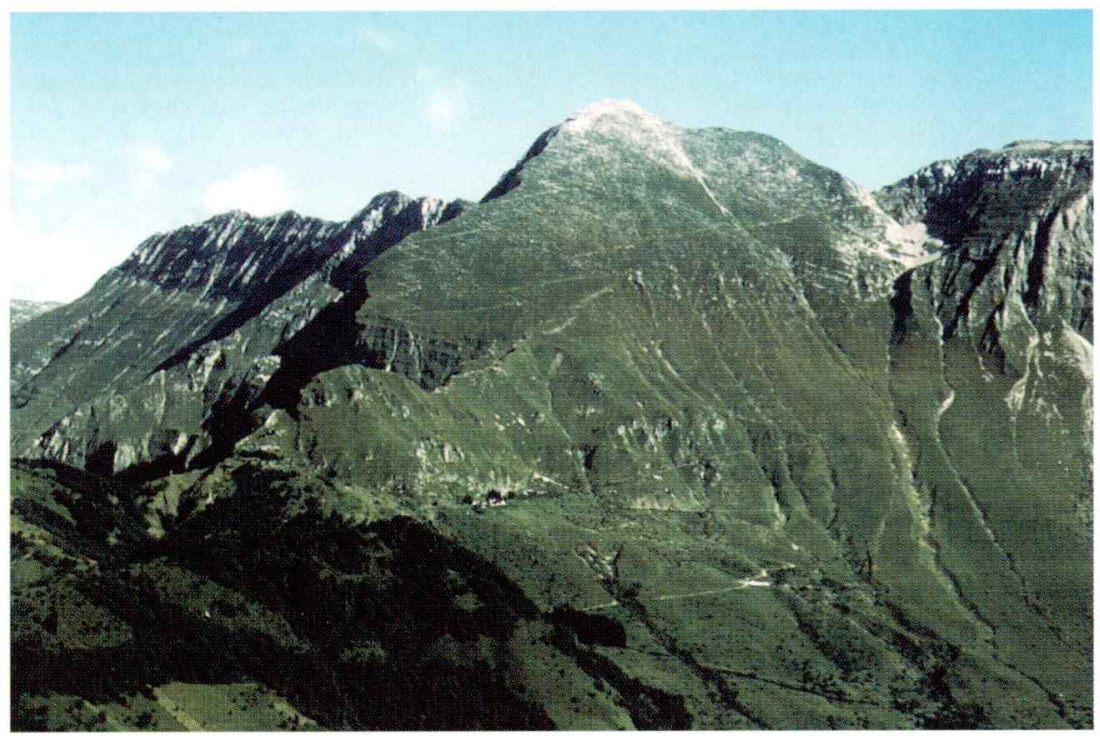

Fig. 1. Massive of Dachstein limestone with $\mathrm{Krn}$ in the foreground, taken from Kolovrat

Sl. 1. Dachsteinski apnenec na Krnu, posnet s Kolovrata 
The Dachstein limestone, or the Dachstein Formation, is of Late Triassic Norian-Rhaetian age. The name is derived from the Dachstein massif near Salzburg. In the larger part of the Julian Alps the formation is developed mostly as thick-bedded limestone and dolomitized limestone (S elli, 1963; Ku š č er et al., 1974; B u s er, 1986, 1987; J urkovšek, 1987;) in places, the bedded limestone passes into more or less extensive reefs of coral limestone (Turnšek \& Buser, 1991). Below the Norian-Rhaetian Dachstein limestone lies a thick succession of layered Main dolomite the lower part of which extends down into the Carnian stage. The development of the Main dolomite and Dachstein limestone in Julian Alps is equal, or very similar as in the wider region of the Northern and Southern Alps (S a nder, 1936; Z ankl, 1967, 1971; Flügel, 1963, 1972; Fischer, 1964, 1975; B osellini, 1967; Bosellini \& Rossi, 1974), Dinaric Mountains (Buser, 1974; Ogorelec, 1975, 1988; Ogorelec \& Rothe, 1993; Dozet, 1990; Herak et al., 1967; Babić, 1968; Dimitrijević \& Dimitrijević, 1988; Čadjenović, 1988), Hungary (Fülöp, 1976; Haas, 1994), and even Sicily (Matavelli et al., 1969; Catala no et al., 1974). This is an indication of unique depositional and paleogegraphic conditions in the wide region of the Northern and Southern Alps and the Mediterranean in Norian and Rhaetian times. Such circumstances were possible only through a sedimentation process of limestone that was equilibrated with sinking of the carbonate platform (F is cher, 1964; B o sellini, 1967).

During the Middle Lias a general disintegration of the entire system of large carbonate plates happened. Breaking and sinking of particular parts was accompanied locally by forming of more or less thick carbonate breccias and neptunian dikes (Bernouilli \& Jenkyns, 1974). Such breccias do not occur in the southern slopes of Krn where the studied traverses is situated, but they are excellently exposed in immediate vicinity, on the Krnska škrbina and near the lake at Lužnica (B a bić, $1980 / 81$; Buser, 1986). The quiet depositional environment on the carbonate platform continued from Rhaetian to Lias, so that the formation of dislocation fissures in the Slovenian part of the Julian Alps, as well as the slope breccias and neptunian dikes took place in Jurassic only, more precisely in the Late Lias. Such cases were recorded also near Bovec and on Mangart (Jurk ov šek et al., 1990).

The traverse on Krn (figs. 2 and 3) covers only the smaller upper part, equal to about one tenth of the entire thickness of the Dachstein limestone. The goal of the presently described study was the recording of lithologic and microfacial characteristics of the limestone especially with the intention of comparison with the beds of the same age in the Southern and Northern Alps. The complex of the Dachstein limestone on Krn is thicker, attaining above 1000 meters; owing to the position of beds and monotonous development of the limestone the investigation was limited to the most diversely developed part of the formation which comprises 30 cyclothems.

The beds underlying the Dachstein limestone on Krn are not exposed. The Lower Jurassic Lias shallow marine limestones that normally overlie the Late Triassic Dachstein limestone are preserved as erosion remnant on the Batognica Mountain, only a few hundred meters southeast of the Krn summit. So it may be concluded that the sampled Dachstein limestones on Krn belong to the upper part of Upper Triassic. The Lias beds have a larger extension in northern slopes of Polovnik northeast of Krn (K uš č er et al., 1974; B u ser, 1987).

The studied massif of the Dachstein limestone belongs in the tectonic sense to a large overthrust structure named after Krn the Krn nappe (Buser, 1986). As the marginal part of the Julian Alps the Krn nappe is thrust over the Rutar nappe (fig. 2) 


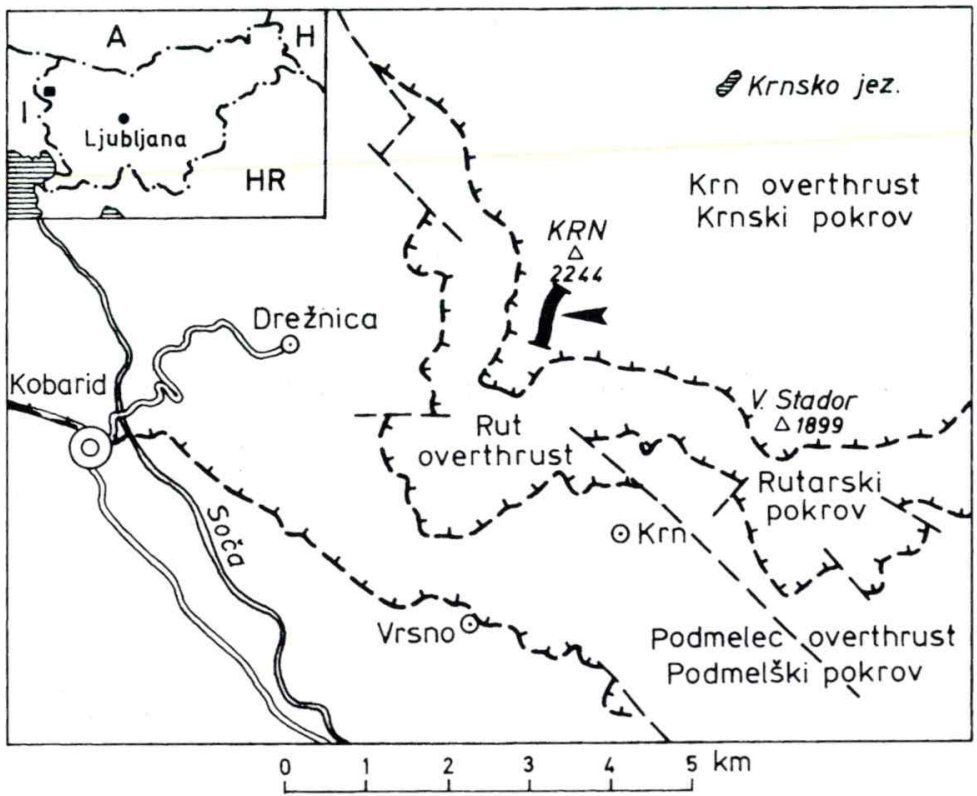

Fig. 2. Structural map of the Krn area and location of the investigated section

Sl. 2. Tektonska karta ozemlja okrog Krna in položaj raziskanega profila

that consists of Jurassic and Cretaceous sediments of the deeper marine development of the Slovenian basin (B u s e r, 1986, 1989).

The limestone on Krn was researched in the frame of the studies for the Basic geologic map 1:100,000, sheet Tolmin and Videm, in 1979 (B u s er, 1986, 1989).

\section{Description of the Traverse}

The Dachstein limestone was examined in a 160 meters thick continuous traverse that is situated on the south slopes of Krn next to the mountaineering trail between the Kožljak saddle and the Gomišček refuge below the Krn summit (fig. 2). The traverse comprises only the upper part of the several hundred meters thick succession with a rather monotonous development of beds. The same textural and lithologic rock types keep repeating up to the summit of $\mathrm{Krn}$. The traverse is throughout its course excellently exposed so that also lateral passages and changes in the rock can be examined.

In the southern slope of Krn the beds of Dachstein limestone dip gently towards northeast $(55 / 25)$. They are to a large degree covered by slope talus and mountain grass, but they may be nevertheless observed in detail in roadcuts of the winding military road that dates from the First World War. The characteristic roof-like south slope of Krn was most probably formed in a large rockslide of limestone beds during the Ice Age, and is not conditioned by the downslope directed dip of the limestone 


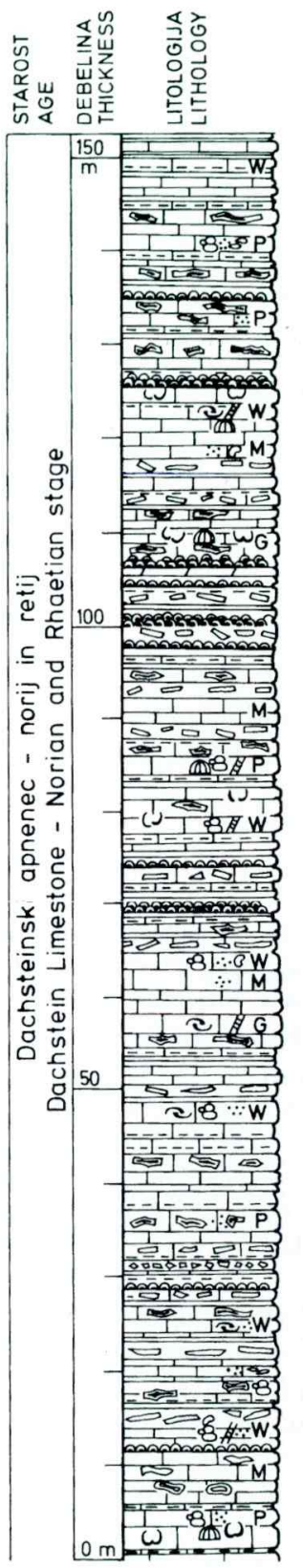

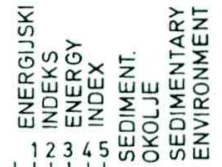

12345 ய̛ํํ는

Hi1

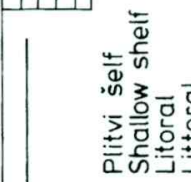

5
5
5
5
5
5
5
5
5
5
5
5
5
5
5
5
5
5
5

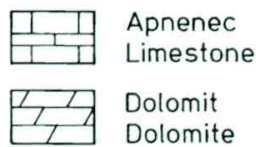

Stromatolitne plasti

Stromatolite

Laminit

Laminite

_. Nadplimski konglomerat

Flat pebble conglomerate

-l-a Izsušitvene pore

Fenestral limestone

$\therefore 000$ Breča

$\Leftrightarrow$ Korozijske votline

Solution cavities

(๑) Onkoidi

Oncoids

$\omega \quad$ Megalodontidne školjke

c Školjke

Pelecypods

\& Foraminifere

Foraminifers

A Alge

O Ostrakodi

Ostracods

(m) Ehinodermi

Echinoderms

Peleti

Pellets

Plastiklasti

Plasticlasts

Strukturni tip kamnine (Dunham, 1962) Textural type of rock
M Mudstone
w Wackestone
P Packstone
G Grainstone

Fig. 3. Lithologic column of the Krn section; Dachstein limestone S1. 3. Litološki stolpec profila Krn; dachsteinski apnenec 
beds, as it is the case for many slopes of the Soča valley. The limestone beds in this slope of roof-like shape dip into the slope.

In the entire traverse alternate cyclically thicker beds of biomicritic limestone and thinner beds, characteristic for deposition in the inter- and supratidal environments. They comprise chiefly the stromatolitic horizons, laminite, loferite and tempestites ("supratidal conglomerate"). Individual cyclothems are from one to five meters thick, 3-4 meters on the average, and exceptionally they attain also 15 meters (fig. 3).

The lithology and sedimentology of the Krn limestone at Krn are similar to that of the Northern Alps (S ander, 1936; Fischer, 1964; Flügel, 1963, 1972; Z ankl, 1967, 1971). Such development was named by Sander the Lofer facies after the Loferer Steinberge massif, and Fischer (1964) introduced for the cyclothemes the term "Lofer Cyclothem". Characteristic for a classic Lofer cyclothem (fig. 4) is alternation of three lithologic members - thinner beds of basal breccia with cement of red or green residual carbonate clay (the A member), stromatolitic or loferitic horizon (B member), and thick beds of biomicritic limestone ( $\mathrm{C}$ member). The Dachstein limestone at Krn shows all characteristics of the Lofer facies, although its development is in a sense specific. On Krn irregularly alternate especially the B and C members, while the basal breccia appears only in two cyclothemes of the investigated traverse. These breccias suggest episodic and short lived interruptions of deposition, i.e. local emersions.

The larger part of the beds in the investigated traverse belongs to the somewhat recrystallized limestone of light olive grey color. It occurs in $30 \mathrm{~cm}$ to $2 \mathrm{~m}$ thick beds, and is typical for deposition in the subtidal environment. According to texture, the limestone is biomicritic and pelmicritic, and it contains usually 10 to $30 \%$ allochems. Among the fossils individual foraminifers (Involutina sp.), skeletal algae (especially of genus Solenopora sp., Thaumatoporella parvovesiculifera Raineri), gastropods, ostracods, echinoderm plates and fragments of bivalve shells. The Norian-Rhaetian age of beds is proved by numerous, up to $20 \mathrm{~cm}$ large megalodontid shells that appear in several beds. Of the megalodontid shells most commonly both valves are preserved. During the early diagenesis the originally probably aragonitic shells were washed out, and their moldic pores were filled by coarse grained fibrous calcite displaying zonal crystal growth. Seldom in parts of these valves also red carbonate clay can be observed. It represents the mechanic residual deposit as an internal sediment. Among the allochems are the most abundant the pellets with frequent up to $5 \mathrm{~mm}$ large micritic plasticlasts admixed to them. The micritic matrix is in places recrystallized to microsparite, while in certain samples it is partly leached out and replaced by fine grained sparite.

The energy index of the sampled rocks is low to very low. It indicates a quiet depositional environment that was only at times moderately agitated. Deposition in littoral environment is suggested primarily by laminite and stromatolitic horizons. The laminite layers are up to $80 \mathrm{~cm}$ thick, and individual laminae measure from a few $\mathrm{mm}$ to $1 \mathrm{~cm}$, and contain numerous sheet and mud cracks. The mineralogy of laminite consists of a mixture of micritic calcite and dolomite. We presume the forming of dolomite during the time of early diagenesis owing to salty pore solutions saturated with $\mathrm{Mg}^{2+}$ ions. The brines were rising through capillary mechanisms in the unconsolidated carbonate mud at times of exposure to the supratidal environment (the "capillary concentration" dolomitization model - Illing et al., 1965). Periodically occurred as a result of tectonic processes breaks and slumps of incompletely lithified 


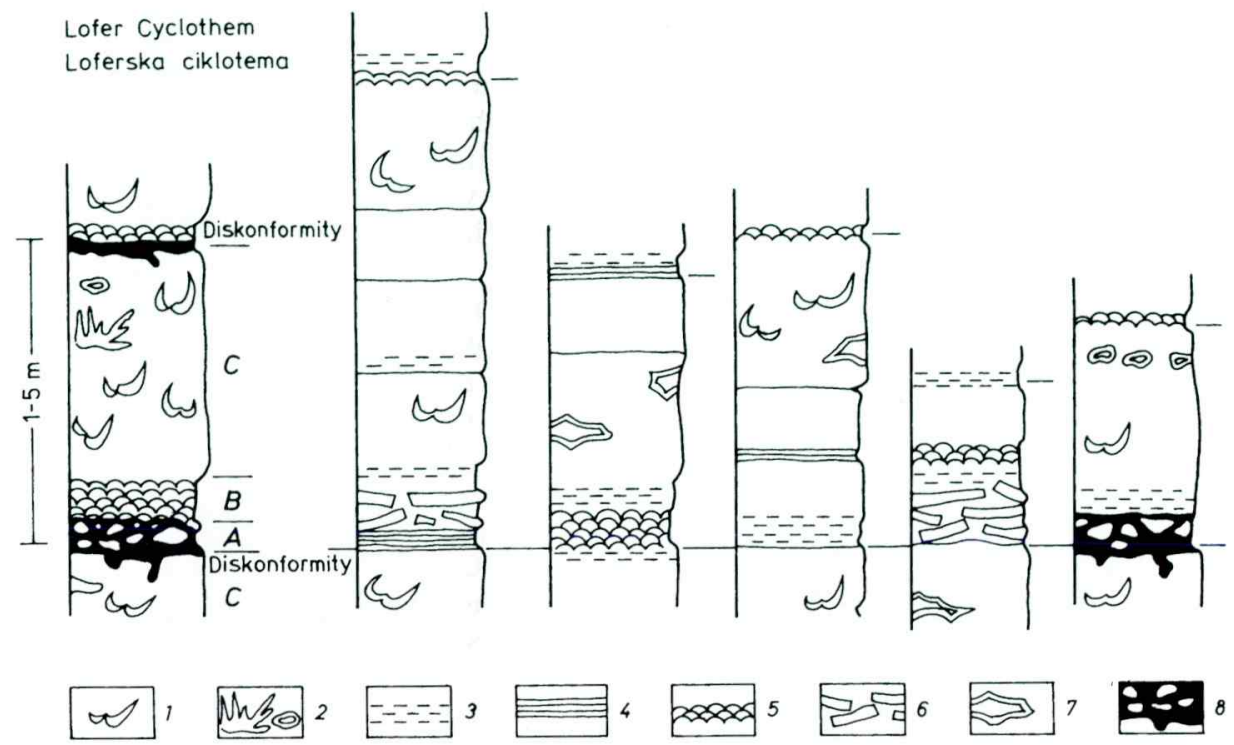

Fig. 4. Different types of cyclothems in the Dachstein limestone from the Krn section. Classical Lofer cyclothem after Fischer (1964) is on the left

1 - Megalodontidae; 2 - Corals and oncoids; 3 - Limestone with shrinkage pores (loferite); 4 Laminite; 5 - Stromatolite; 6 - Tempestite layers ("flat pebble conglomerate") with carbonate blocks; 7 - Solution cavity; 8 - Breccia with residual carbonate clay

Lofer cyclothem: member $A$ - Red or green residual sediment enriched by clay and iron minerals; residue of weathered material; member $B$ - Laminated and dolomitised stromatolite or loferite; intertidal environment of deposition; member $C$ - Megalodon limestone; subtidal environment

Sl. 4. Različni tipi ciklotem, ki se javljajo v dachsteinskem apnencu na Krnu. Levo je klasična loferska ciklotema po Fischerju (1964)

1 - Megalodonti; 2 - Korale in onkoidi; 3 - Apnenec z izsušitvenimi porami (loferit); 4 - Laminit; 5 - Stromatolit; 6 - Tempestitne plasti ("nadplimski konglomerat") s karbonatnimi bloki; 7 Korozijske votline; 8 - Breča z residualno karbonatno glino

Loferska ciklotema: člen $A$ - Rdeči ali zeleni residualni sediment, bogat z glino in železovimi minerali; preperinski material; člen $B$ - Pasoviti, dolomitizirani stromatolit ali loferit; medplimsko okolje sedimentacije; člen $C$ - Megalodontidni apnenec; podplimsko okolje sedimentacije

parts of the limy bottom. Up to $80 \mathrm{~cm}$ long and up to $10 \mathrm{~cm}$ thick carbonate slabs or scales were formed, and they give to the rock the appearance of "flat pebble conglomerate", (fig. 5). These carbonate slabs are often turned up and curved at margins along the longitudinal axis. Fissures between slabs are filled by granular calcitic sparite. In literature such sediments are known as tempestites (Aigner, 1982). The origin and classification of sedimentary structures formed in the supratidal environment owing to disiccation and breaking of incompletely lithified carbonate laminae and bands were described in Upper Triassic beds of the Dolomites by A s s e r e to and Kendall (1977). They named such structures "tepee", the term for Indian tent of pyramidal shape. 


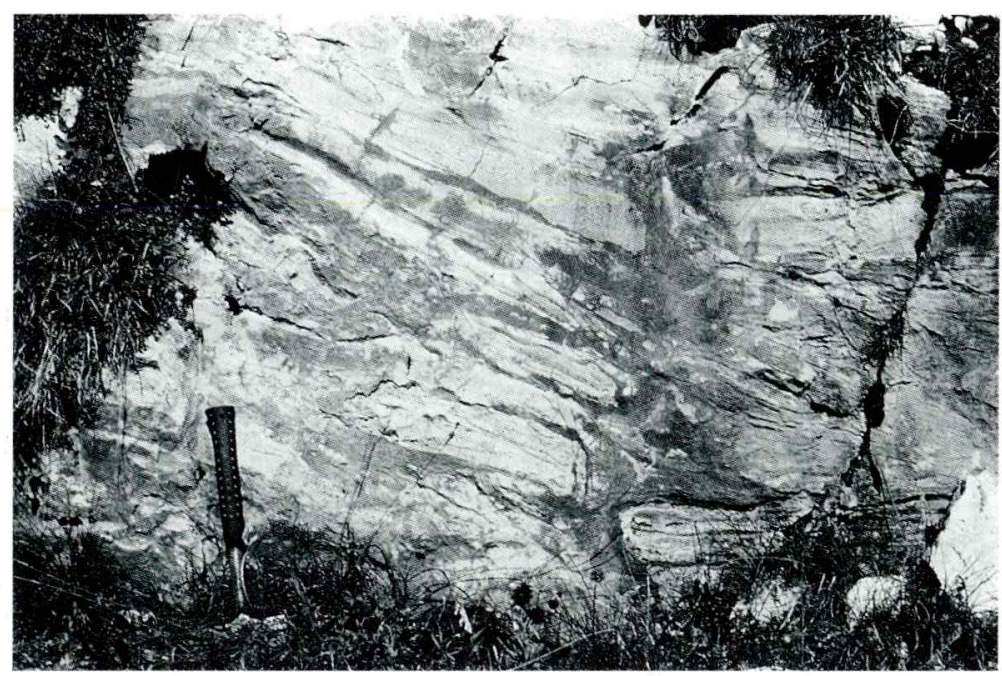

Fig. 5. Large carbonate blocks, mostly of loferitic and stromatolitic origin, composing tempestite

Sl. 5. Velike raztrgane karbonatne luske, po sestavi pretežno loferitne in stromatolitne, ki grade tempestit

The stromatolitic horizons are up to $40 \mathrm{~cm}$ thick, and they are more frequent mostly in the middle part of the traverse. The larger part is a stromatolite of polygonal type (Aitken, 1967; Gebelein, 1969), with up to $2 \mathrm{~mm}$ thick parallel laminae. The horizons of spongy texture are very rare (pl. 3, fig. 1). The interspaces of stromatolitic laminae and tiny disiccation pores (fenestrae, shrinkage pores) are filled by transparent sparitic cement, and in certain larger pores also geopetal structures with internal micrite can be found (pl. 2, fig. 1). Stromatolitic horizons are prevailingly in part dolomitized. The proportion of dolomite which is microcrystalline and associated with organic laminae is estimated at between 5 and $19 \%$. Forming of dolomite in stromatolitic layers is connected with early diagenetic processes in the supratidal environment with an intense activity of microorganisms. The cyanophytes that participating in formation of stromatolites caused with their decay an increase in $\mathrm{CO}_{3}{ }^{--}$ions in the microenvironment which promoted the crystallization of dolomite (Gebelein \& Hoffman, 1973). Owing to increased contents of organic matter in the sediment during growth of stromatolites these beds are of darker color than the country rock, and can be macroscopically distinguished in the field.

A special lithology of rock characteristic for the supratidal environment is the micritic and pelmicritic limestone with disiccation marks (pl. 1, fig. 1-2, pl. 2, fig. 2-3). Layers of this limestone, called loferite after F is cher (1964), are quite frequent in the traverse, and are up to $50 \mathrm{~cm}$ thick. The mud cracks measure up to several $\mathrm{mm}$ and are oriented with their longer axis parallel to bedding. The features are a consequence of drying and shrinkage of unconsolidated carbonate mud during the phases of the supratidal environment, and their share might attain $40 \%$ of the rock. They are filled with coarse grained sparite, while in larger vugs also internal micritic sediment and gravitational (stalactitic) cement can be found (pl. 2, fig. 3). The latter 
is typical for diagenesis under meteoric conditions, an indication of episodic exposure of the limestone during sedimentation above the sea level.

In the lower part of traverse in places thinner layers of oncoid limestone can be seen. The oncoids measure up to $3 \mathrm{~cm}$ and display typical concentric structure with numerous algal envelopes (pl. 3, fig. 2-3). They are slightly dolomitized, like the stromatolitic laminae. Individual oncoids are often overgrown. The origin of oncoids is associated with a slightly more agitated environment, with tidal channels in which the tidal currents enabled steady movement and their concentric growth.

In the entire traverse occur in several layers also solution cavities measuring several $\mathrm{cm}$ to a few $\mathrm{dm}$. They are an indication of episodic emersions of Dachstein limestone, and they represent paleokarstic passages and caves. They are filled by several generations of variously colored sparitic calcite, so that they display a variegated cocade structure. Especially pretty and large solution cavities are developed on Krn summit where they are often filled also with red residual carbonate clay (fig. 6, pl. 2, fig. 4). The limestone with numerous variegated solution cavities is an interesting ornamental stone.

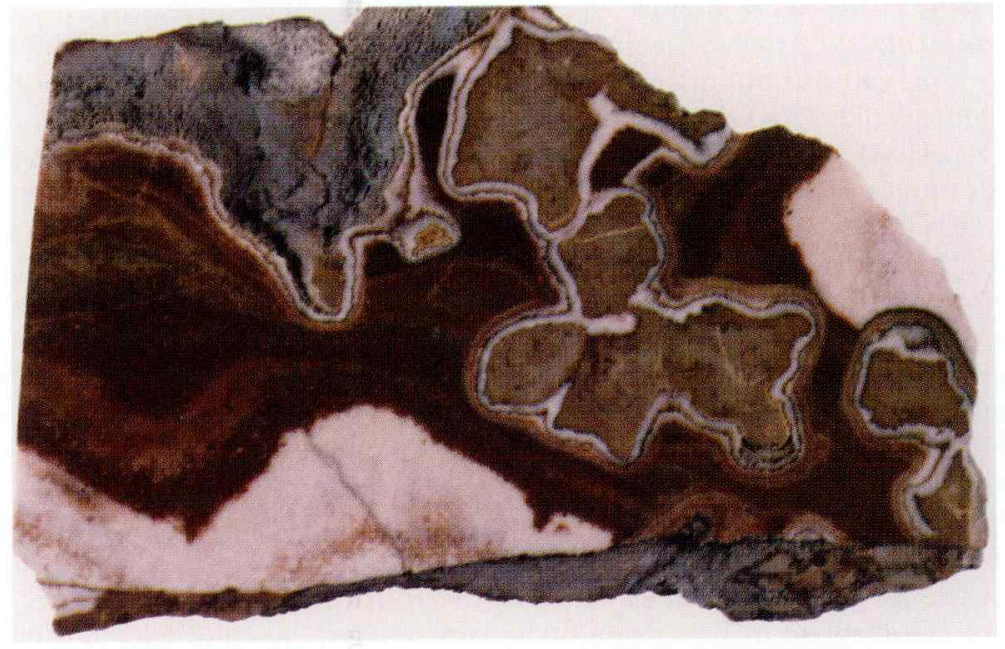

Fig. 6. A detail of the solution cavity filled by sparry radial calcite and red carbonaceous clay; the top of Krn, natural size

Sl. 6. Detajl korozijske votline, ki jo zapolnjujeta conarni sparitni kalcit in rdeča karbonatna glina; vrh Krna, naravna velikost

\section{Paleogeographic Conditions during Forming of Dachstein Limestone}

The Upper Triassic rocks that build the predominant part of the geotectonic unit of the Southern Alps, to which also the Krn area with the studied traverse belongs, were deposited on the Julian carbonate platform that was formed at the beginning of the Late Triassic. South of this platform extended the deeper marine Slovenian basin that wedged out in the area of the present central Soča valley between Kobarid and 
Srpenica. Owing to wedging out of the Slovenian basin the Julian and the Dinaric carbonate platforms bordered westwards directly one to the other, and continued farther west to neighboring Italy as a unique Trento platform (Buser \& Debeljak, 1996).

The depositional circumstances on the Dinaric and Julian platforms were different during the Late Triassic, as indicated by the Main dolomite that contains only rare megalodontid bivalves on the Dinaric platform (Ogorelec \& Rothe, 1993), while these are extraordinarily numerous in the $\mathrm{C}$ member on the northerly situated Julian platform.

Characteristic for the Dachstein limestone in the described traverse on Krn is the outstanding appearance of large solution vugs and tempestites, or the "flat pebble conglomerate". This is typical in the Julian Alps also in the environs of Krn on Polovnik, in the Soča valley southeast of Bovec and in Bohinj along the road from the Voje valley to the Blato pasturage. Especially characteristic are cavities in which the walls are rimmed by calcite of zonal texture, while the centers are filled by red, yellow to violet carbonate clay. In other areas the cavities are less frequent, and they are mostly filled by calcite only. An interesting fact is that solution cavities occur only in limestone layers that were deposited in the subtidal environment of the carbonate platform, and that they never reach into the stromatolitic and laminated layers.

The extraordinary abundance of solution cavities indicates special condition during their genesis. The margin of the carbonate platform, on which the limestone of Krn was deposited, was the most exposed part to frequent uplifts of the sea bottom or to oscillations of the sea level, and with that to longer land phases. During these events occurred intense karstification and forming of insoluble argillaceous residue, or fossil soils, that were washed to central parts of solution cavities. There is the still open question on the absence of these cavities in the stromatolitic and laminated layers. There they also could be logically expected, since during land phases also these beds were subjected to weathering. One of possible explanations might be also that the stromatolitic beds were more resistant against karstification than pure limestone owing to their high dolomite content.

The beds of the Dachstein limestone in the examined traverse on Krn were deposited on the extreme southern shallow marine margin of the carbonate platform, and they border at present with the tectonic overthrust contact on the southerly lying deposits of the Slovenian basin. Along the thrust border probably only an insignificant part of the Dachstein limestone beds were eroded, so that the southern part of the old carbonate platform remains more or less preserved.

In the southern slope of Veliki Stador southeast of Krn are still preserved the Norian-Rhaetian reef limestones that represent the lateral equivalent of the bedded Dachstein limestone (Turnšek \& B u s er, 1991). These limestones are an additional indication of the extreme southern margin of the Julian carbonate platform on which in places just along its flexure the coral reefs thrived.

The origin of tempestites in the area of the present Krn cannot be reliably explained by stormy events. Up to one meter long and several decimeters thick, half lithified limestone slabs could not have been formed by such events. Furthermore, on these slabs there are no traces of shorter or longer transport. The slabs are not limited by sharp cracks that could be formed at surface drying of limy mud. The joints between them are "welded", filled by calcitic sparite. The origin of tempestites is explained by the present authors by episodic earthquake events that caused cracking and slumping of still unconsolidated limy mud. The earthquakes were the most fre- 
quent and strong exactly along the border of the platform that sunk along steep faults into the southerly extending Slovenian basin. The extraordinary exposition of this part of the carbonate platform to tectonic effects is indicated in a later time (Late Lias) by deep, wide open tension fault cracks that were filled by breccias with red cement in the form of neptunian dikes. These very phenomena are spatiually associated with the wider area of Krn where numerous tempestite layers occur.

\section{Conclusion}

The lithology and microfacies of the Norian-Rhaetian Dachstein limestone at Krn suggest that the rock was deposited in a very shallow sea. The textural types of limestone indicate incessant altenation of supra- and subtidal depositional environment. For the supra- and intratidal environment are typical the stromatolitic beds, mud cracks, limestone with shrinkage pores (loferite) and flat pebble conglomerate. According to the Standard Microfacies classification (SMF) and the Facies Belt classification (FB, Wilson, 1975; Flügel, 1978) the dolomitized stromatolitic and loferitic limestones of the intratidal environment may be attributed to 19 and 20 SMF and 8 to $9 \mathrm{FB}$ (restricted platform and littoral evaporites). The majority of limestone was deposited in a very shallow water that was not deeper than 10 to 20 meters. The energy index of examined samples is low to very low which leads to the idea of quiet depositional conditions in the restricted part of the carbonate platform with local lagoons. The limestones of the subtidal environment show indications of standard microfacies (SMF) 8, 9, 13 and 18 (biomicrite, biosparite, oncoidal grainstone, foraminiferal and algal limestone), and belong to the environment of open to partly restricted carbonate platform (FB 7 and 9). The enumerated characteristics and monotonous development of the Dachstein limestone in the extended region of the Alps, as well as its impressive thickness suggest a rather flat paleorelief. The carbonate platform sank very slowly, and also the deposition was taking course in equilibrium with sinking. The limestone emerged locally many times, and was exposed to paleokarstification, as indicated by numerous solutioin cavities filled by sparitic calcite (sinter) and residual carbonate clay.

A similar development of the Dachstein limestone with numerous cyclothems as that on Krn is known from a wider region of west Slovenia, especially in the Julian Alps, as for example in the Kanin mountains, Trenta (Jurkovšek et al., 1990), Pokljuka and Kobariški Stol (Bus er, 1986, 1987), Polovnik (Kuščer et al., 1974), and from Trnovski gozd and margin of the Banjška planota (O gorele c, 1975, 1988; Ogorelec \& R othe, 1993).

Characteristic for the Dachstein limestone of the entire mentioned region are all the elements of the classic Lofer development for which is typical the predominance in these cyclothems of the $\mathrm{B}$ and $\mathrm{C}$ members, and extreme rarity of basal breccias with residual clay (A member).

The very frequent solution cavities were formed in the uppermost southern part of the Dinaric Julian carbonate platform that was the most exposed to long lasting land phases, or at least more often than the northerly lying lagoonal region. Since these cavities appear only in limestone ( $\mathrm{C}$ member) of the cyclothem, and not in the B layers of cyclothem (stromatolitic layer), this might be the reason for less intense karstification of early diagenetically dolomitized stromatolitic layers than the corresponding limestone layers. The origin of tempestites is associated with frequent earth- 
quakes that caused cracking and slumping in the still unconsolidated limestone beds. The most intense earthquakes occurred just at the edge of the Julian carbonate platform and the southerly lying Slovenian basin where the Dachstein limestone of the studied traverse was formed.

\section{Razvoj dachsteinskega apnenca na Krnu v Julijskih Alpah}

\section{Uvod}

Ko se približamo srednjemu Posočju, se naš pogled ustavi na obsežnih gorskih masivih Julijskih Alp, med katerimi posebno izstopa mogočni vrh Krna (sl. 1). Te masive v večjem delu gradi prek 1000 metrov debela skladovnica svetlega in debeloplastnatega apnenca, v geološki literaturi znanega kot dachsteinski apnenec.

Dachsteinski apnenec oziroma dachsteinska formacija je zgornjetriasne, noriškoretijske starosti. Ime ima po masivu Dachstein pri Salzburgu. V večjem delu Julijskih Alp je razvit predvsem kot debeloplastnati apnenec in dolomitizirani apnenec (Selli, 1963; Buser, 1986, 1987; Jurkovšek, 1987; Kuščer et al., 1974); sem in tja pa plastnat apnenec prehaja v bolj ali manj obsežne grebene koralnega apnenca (Turnšek \& Buser, 1991). Pod norijsko-retijskim dachsteinskim apnencem leži debela skladovnica plastnatega glavnega dolomita, katerega nižji del sega še v karnijsko stopnjo. Razvoj glavnega dolomita in dachsteinskega apnenca je v Julijskih Alpah enak ali zelo podoben kakor na širšem prostoru Severnih in Južnih Alp (S a nder, 1936; Z ankl, 1967, 1971; Flüge 1, 1963, 1972; Fischer, 1964, 1975; B osellini, 1967; Bosellini \& Rossi, 1974), Dinarskega gorstva (Buser, 1974; Ogorelec, 1975, 1988; Ogorelec \& Rothe, 1993; Dozet, 1990; Herak et al., 1967; B a bić, 1968; Dimitrijević \& Dimitrijević, 1988; Čadjenović, 1988), Madžarske (Fülöp, 1976; Ha a s, 1994) in celo Sicilije (Matavelli et al., 1969; Catalano et al., 1974). To kaže na enotne sedimentacijske in paleogeografske razmere na širšem prostoru Severnih in Južnih Alp ter delu Mediterana v noriju in retiju. To je bilo možno le z uravnoteženim procesom sedimentacije apnenca in tonjenja karbonatne platforme (F is cher, 1964; B os ellini, 1967).

V srednjem liasu je prišlo do splošnega razkosanja celega sistema velikih karbonatnih plošč. Lomljenje in tonjenje njenih posameznih delov je lokalno spremljalo nastajanje bolj ali manj debelih karbonatnih breč in neptunskih dajkov (B ernouilli \& J enkyns, 1974). Te breče na samem južnem pobočju Krna, kjer leži posneti profil, niso prisotne, so pa odlično odkrite v njegovi neposredni bližini, na Krnski škrbini in pri jezeru v Lužnici (B a b i ć, 1980/81; B u ser, 1986). Mirne sedimentacijske danosti na karbonatni platformi so se iz retija nadaljevale še v lias, tako da je prišlo do nastanka prelomnih razpok na slovenskem delu Julijskih Alp in pobočnih breč ter neptunskih dajkov šele v juri oziroma v zgornjem liasu. Taki primeri so tudi pri Bovcu in na Mangartu (Jurk o v š ek et al., 1990).

S profilom na Krnu (sl. 2 in 3) smo zajeli le manjši vrhnji del, okrog desetino celotne formacije dachsteinskega apnenca. Namen te raziskave je namreč bil, da ugotovimo litološke in mikrofacialne značilnosti apnenca predvsem zaradi primerjave z enako starimi plastmi v Južnih in Severnih Alpah. Sam kompleks dachsteinskega apnenca na Krnu je sicer debelejši in doseže preko 1000 metrov, vendar smo se zaradi 
lege plasti in monotonega razvoja apnenca omejili le na najbolj pestro razviti del formacije, s katerim smo zajeli 30 ciklotem.

Talnina dachsteinskega apnenca na Krnu ni odkrita. Spodnjejurski liasni plitvomorski apnenci, ki ležijo normalno nad zgornjetriasnim dachsteinskim apnencem, so ohranjeni kot erozijska krpa na hribu Batognica le nekaj sto metrov jugovzhodno od vrha Krna. Tako lahko sklepamo, da pripadajo vzorčevani dachsteinski apnenci na Krnu vrhnjemu delu zgornjega triasa. Večji obseg pa imajo liasne plasti na severnem pobočju Polovnika, severovzhodno od Krna (K u šč er et al., 1974; B us er, 1987).

Tektonsko pripada raziskani masiv dachsteinskega apnenca obsežnemu pokrovu, ki ima ime prav po Krnu - Krnski pokrov (B u s er, 1986). Kot robni del Julijskih Alp je Krnski pokrov narinjen na Rutarski pokrov (sl. 2), katerega grade jurski in kredni sedimenti globljevodnega razvoja Slovenskega bazena (B u s e r, 1986, 1989).

Apnenec na Krnu smo posneli v okviru raziskav za Osnovno geološko karto 1:100.000, list Tolmin in Videm, leta 1979 (B us e r, 1986, 1987).

\section{Opis profila}

Dachsteinski apnenec smo raziskali v 160 metrov debelem sklenjenem profilu, ki poteka po južnem pobočju Krna ob planinski poti med prevalom Kožljak in Gomiščkovim zavetiščem pod vrhom Krna (sl. 2). Profil zajema le vrhnji del več sto metrov debele skladovnice s precej monotonim razvojem plasti. Isti strukturni in litološki tipi kamnine se ponavljajo vse do vrha Krna. Profil je vseskozi odlično odkrit, tako da opazujemo lepo tudi bočne prehode in spremembe v kamnimi.

Plasti dachsteinskega apnenca vpadajo na južnem pobočju Krna pod blagim kotom proti severovzhodu (55/25). Večji del so pokrite s pobočnim gruščem in planinsko travo, vendar jih je moči kljub temu lepo opazovati v vsekih vijugasto speljane vojaške poti iz prve svetovne vojne. Značilno strehasto oblikovano južno pobočje Krna je verjetno nastalo ob velikem podoru apnenčevih plasti v ledeni dobi in ni pogojeno z vpadom apnenčevih plasti po pobočju navzdol, kot je to pri številnih pobočjih v dolini Soče. Apnenčeve plasti na tem strehi podobnem pobočju vpadajo v samo pobočje.

$\mathrm{V}$ celotnem profilu se ciklično menjavajo debelejše plasti biomikritnega apnenca in tanjše plasti, značilne za sedimentacijo v med - in nadplimskem okolju. To so predvsem stromatolitni horizonti, laminit, loferit in tempestiti ("nadplimski konglomerat"). Posamezne cikloteme so debele od enega do pet metrov, povprečno 3-4 metre, izjemoma pa dosežejo tudi do petnajst metrov (sl. 3).

Litološko in sedimentološko je apnenec na Krnu razvit podobno kot v Severnih Alpah (S a nder, 1936; F is cher, 1964; Flüg el, 1963, 1972; Z a n kl, 1967, 1971). Tak razvoj je Sander imenoval po masivu Loferer-Steinberge loferski facies, F is cher (1964) pa je za cikloteme uvedel termin "loferska ciklotema". Za klasično lofersko ciklotemo (sl. 4) je značilno menjavanje treh litoloških členov - tanjših plasti bazalne breče $\mathrm{z}$ vezivom rdeče ali zelene residualne karbonatne gline (člen A), stromatolitnega ali loferitnega horizonta (člen B) in debelih plasti biomikritnega apnenca (člen C). Dachsteinski apnenec na Krnu kaže vse značilnosti loferskega faciesa, vendar je razvit nekoliko svojsko. Na Krnu se nepravilno menjavata predvsem člena B in C, medtem ko se bazalna breča javlja le v dveh ciklotemah raziskanega profila. Te breče nakazujejo občasne in kratkotrajne prekinitve v sedimentaciji oziroma lokalne okopnitve. 
Večji del raziskanega profila oziroma plasti pripada nekoliko rekristaliziranemu apnencu svetlo olivno sive barve. Javlja se v $30 \mathrm{~cm}$ do 2 metra debelih plasteh in je značilen za sedimentacijo v podplimskem pasu (subtidal environment). Po strukturi je apnenec biomikriten in pelmikriten ter vsebuje navadno 10 do $30 \%$ alokemov. Med fosili opazujemo posamezne foraminifere (Involutina sp.), skeletne alge (predvsem iz rodu Solenopora sp., Thaumatoporella parvovesiculifera Raineri) gastropode, ostrakode, ploščice ehinodermov in odlomke školjčnih lupin. Norijsko-retijsko starost plasti dokazujejo številne, do $20 \mathrm{~cm}$ velike megalodontidne školjke, ki se javljajo v več plasteh. Megalodontidne školjke so največkrat ohranjene z obema lupinama. V času zgodnje diageneze so bile prvotno verjetno aragonitne lupine izlužene, njihove moldične pore pa je zapolnil debelozrnati vlaknati kalcit s conarno rastjo kristalov. Poredko opazujemo $\mathrm{v}$ delih teh lupin tudi rdečo karbonatno glino, ki predstavlja mehanski rezidualni nanos kot interni sediment. Med alokemi so najpogostnejši peleti, mednje pa so večkrat pomešani še do $5 \mathrm{~mm}$ veliki mikritni plastiklasti. Mikritna osnova je ponekod rekristalizirana v mikrosparit, v nekaterih vzorcih pa je tudi delno izprana in nadomeščena z drobnozrnatim sparitom.

Energijski indeks vzorcev je nizek do zelo nizek. Kaže na mirno sedimentacijsko okolje, ki je bilo le občasno nekoliko razgibano. Sedimentacijo v litoralnem okolju nakazujejo predvsem laminit in stromatolitni horizonti. Plasti laminita so debele do $80 \mathrm{~cm}$, posamezne lamine pa merijo od nekaj mm do $1 \mathrm{~cm}$ in vsebujejo številne izsušitvene razpoke (sheet \& mud cracks). Mineralna sestava laminita je mešanica mikritnega kalcita in dolomita. Predvidevamo, da je dolomit nastal v času zgodnje diageneze zaradi slanih pornih raztopin, nasičenih $\mathrm{z} \mathrm{Mg}^{2+}$ ioni, ki so se kapilarno dvigale $\mathrm{v}$ nekonsolidiranem karbonatnem blatu, v času, ko je bil ta izpostavljen nadplimskim razmeram ("capillary concentration" model dolomitizacije - Illin g et al., 1965). Občasno je zaradi tektonskih procesov prišlo do lomljenja in zdrsa še nepopolnoma litificiranih delov apnenčevega dna. Nastale so do $80 \mathrm{~cm}$ dolge in okoli $10 \mathrm{~cm}$ debele karbonatne plošče oz. luske, ki dajejo nakopičene kamnini videz nadplimskega konglomerata ("flat pebble conglomerate", - sl. 5). Karbonatne plošče oziroma luske so ob robovih podolžne osi mnogokrat zavihane ali usločene. Razpoke med ploščami zapolnjuje zrnati kalcitni sparit. V literaturi so taki sedimenti znani kot tempestiti (A igner, 1982). Nastanek in klasifikacijo sedimentnih tekstur, ki so nastale v nadplimskem okolju zaradi izsuševanja in lomljenja še nepopolnoma litificiranih karbonatnih lamin in pasov, sta iz zgornjetriasnih plasti Dolomitov opisala As s e reto in Kendall (1977). Take teksture sta poimenovala "tepee" (originalni izraz za piramidasto obliko indijanskega šotora).

Stromatolitni horizonti so debeli do $40 \mathrm{~cm}$ in so pogostejši predvsem v srednjem delu profila. Večji del je stromatolit poligonalnega tipa (A itken, 1967; Geb elein, 1969), z do $2 \mathrm{~mm}$ širokimi in vzporednimi laminami. Horizonti s spužvasto strukturo so zelo redki (tab. 3, sl. 1). Medprostore stromatolitnih lamin in drobne izsušitvene pore (fenestrae, shrinkage pores) zapolnjuje prozorni sparitni cement, v nekaterih večjih porah pa opazujemo tudi geopetalne teksture $\mathrm{z}$ internim mikritom (tab. 2, sl. 1). Stromatolitni horizonti so povečini nekoliko dolomitizirani. Delež dolomita, ki je mikrokristalen in vezan na organske lamine, cenimo med 5 in $10 \%$. Nastanek dolomita $\mathrm{v}$ stromatolitnih plasteh povezujemo z zgodnjediagenetskimi procesi $\mathrm{v}$ nadplimskem okolju ob intenzivni udeležbi mikroorganizmov. Cianobakterije, ki so udeležene pri nastanku stromatolitov, povzročajo namreč pri svojem razpadanju povišanje $\mathrm{CO}_{3}^{--}$ionov v mikrookolju, kar pospešuje kristalizacijo dolomita (G e b elein \& Hoffman, 1973). Zaradi povišane vsebnosti organske primesi v sedimentu med 
rastjo stromatolitov so te plasti obarvane temneje kot prikamnina, tako da že po barvi makroskopsko izstopajo na terenu.

Poseben litološki tip kamnine, značilen za nadplimsko okolje, je mikritni in pelmikritni apnenec z izsušitvenimi porami (tab. 1, sl. 1-2, tab. 2, sl. 2-3). Plasti tega apnenca, po Fis cherju (1964) imenovane loferit, so precej pogoste v celotnem profilu in so debele do $50 \mathrm{~cm}$. Izsušitvene pore merijo do nekaj $\mathrm{mm}$ in so z daljšo osjo orientirane vzporedno s plastovitostjo kamnine. Pore so nastale z izsuševanjem in krčenjem nekonsolidiranega karbonatnega blata $\mathrm{v}$ fazah nadplimskega okolja in dosežejo tudi do $40 \%$ kamnine. Zapolnjuje jih debelozrnati sparit, v večjih porah pa opazujemo tudi interni mikritni sediment in gravitacijski (stalaktitični) cement (tab. 2, sl. 3). Slednji je značilen za diagenezo pri meteorskih razmerah, kar kaže na to, da je bil apnenec med sedimentacijo občasno nad nivojem morske gladine.

V spodnjem delu profila opazujemo ponekod tanjše plasti onkoidnega apnenca. Onkoidi merijo do $3 \mathrm{~cm}$ in kažejo značilno koncentrično zgradbo s številnimi algnimi ovoji (tab. 3, sl. 2-3). Ti so enako kakor pri stromatolitnih laminah rahlo dolomitizirani. Večkrat se onkoidi med seboj preraščajo. Nastanek onkoidov je vezan na nekoliko bolj razgibano okolje, na medplimske kanale (tidal channels), kjer so jim tokovi zaradi bibavice omogočali stalno gibanje in koncentrično rast.

$\mathrm{V}$ celotnem profilu se v več plasteh javljajo tudi korozijske votline (solution cavities), ki merijo od nekaj cm do več dm. Po njih sklepamo na občasne okopnitve dachsteinskega apnenca in predstavljajo paleokraške kanale in votline. Zapolnjuje jih več generacij različno obarvanega sparitnega kalcita, tako da kažejo barvno pisano kokardno teksturo. Posebno lepe in velike korozijske votline so razvite na vrhu Krna, kjer so večkrat zapolnjene tudi z rdečo karbonatno residualno glino (sl. 6, tab. 2, sl. 4). Apnenec s številnimi pisanimi korozijskimi votlinami je zanimiv kot okrasni kamen.

\section{Paleogeografske razmere pri nastajanju dachsteinskega apnenca}

Zgornjetriasne kamnine, ki sestavljajo pretežni del geotektonske enote Južnih Alp, kamor spada tudi območje Krna s posnetim profilom, so nastale na Julijski karbonatni platformi, ki je bila formirana na začetku zgornjega triasa. Južno od te platforme je bil globljemorski Slovenski bazen, ki se je na predelu osrednjega Posočja med Kobaridom in Srpenico izklinjal. Proti zahodu sta zaradi izklinitve Slovenskega bazena mejili neposredno ena na drugo Julijska in Dinarska karbonatna platforma, ki sta se nadaljevali proti zahodu kot enojna Trento platforma v sosednjo Italijo (Buser \& Debeljak, 1996).

Sedimentacijske okoliščine na Dinarski in Julijski karbonatni platformi so bile v zgornjem triasu različne, saj dobimo danes na Dinarski platformi glavni dolomit, ki vsebuje le maloštevilne megalodontidne školjke, medtem ko so te na severno ležeči Julijski platformi v členu C izredno številne (O g o r elec \& R o the, 1993).

Za dachsteinski apnenec $\mathrm{v}$ posnetem profilu na Krnu je značilno izredno pogostno pojavljanje velikih korozijskih votlin in tempestitov oziroma "nadplimskega konglomerata". Ta značilnost se pojavlja v Julijskih Alpah še v sosedstvu Krna na Polovniku, v dolini Soče jugovzhodno od Bovca in v Bohinju ob cesti iz doline Voj na planino Blato. Še posebno so značilne votline, katerih stene obroblja kalcit s conarno strukturo, njen osrednji del pa zapolnjuje rdeča, rumena do vijoličasto obarvana karbonatna glina. Na drugih območjih so te votline manj številne in so večidel zapol- 
njene le s kalcitom. Zanimivo je, da dobimo korozijske votline le v apnenčevih plasteh, ki so nastale v podplimskem območju karbonatne platforme in ne segajo nikjer tudi v stromatolitne in laminirane plasti.

Izredna pogostnost korozijskih votlin in tempestitov kaže na posebne okoliščine med nastajanjem. Rob karbonatne platforme, na katerem je nastal apnenec na Krnu, je bil najbolj izpostavljen pogostnim dvigovanjem morskega dna oziroma oscilaciji morja in s tem dolgotrajnejšim okopnitvam. Ob tem je prihajalo do intenzivnega zakrasovanja in nastajanja glinenega netopnega ostanka ali fosilnih tal, ki so bila sprana v osrednje dele korozijskih votlin. Ostalo je še odprto vprašanje, zakaj se te votline ne pojavljajo tudi v stromatolitnih in laminiranih plateh. To bi bilo tudi logično pričakovati, saj so bile ob nastanku kopnega tudi te plasti izpostavljnene preperevanju. Ena izmed možnostnih razlag je lahko tudi ta, da so bile stromatolitne plasti zaradi visoke vsebnosti dolomita odpornejše proti zakrasovanju kakor čisti apnenec.

Plasti dachsteinskega apnenca v posnetem profilu na Krnu so nastale na skrajnem južnem plitvomorskem robu karbonatne platforme in danes mejijo s tektonskim narivnim kontaktom na južneje ležeče sedimente Slovenskega bazena. Ob narivnem robu je bil verjetno po njegovem nastanku erodiran le neznatni del plasti dachsteinskega apnenca in je ob tem ostal bolj ali manj ohranjen južni rob nekdanje karbonatne platforme.

Na južnem pobočju Velikega Stadorja, jugovzhodno od Krna so ohranjeni še norijsko-retijski grebenski apnenci, ki predstavljajo lateralni ekvivalent skladovitega dachsteinskega apnenca (Turnš ek \& B user, 1991). Tudi ti apnenci kažejo na skrajni južni rob Julijske karbonatne platforme, ob katerem so ponekod tik ob njenem pregibu v bazen uspevali koralni grebeni.

Nastanek tempestitov na območju današnjega Krna zanesljivo ne moremo razložiti z neurnimi ali nevihtnimi dogodki. Do meter dolgih in nekaj deset centimetrov debelih napol litificiranih apnenčevih plošč taki dogodki niso mogli povzročiti. Na teh ploščah tudi ni opaziti sledov krajšega, kaj šele daljšega transporta. Plošč ne ločijo ostre razpoke, ki nastajajo ob površinskem izsuševanju apnenčevega blata. Stiki med njimi so "zaliti" oziroma zapolnjeni s kalcitnim sparitom. Nastanek tempestitov tolmačiva z občasnimi potresnimi dogodki oziroma sunki, ki so povzročili prelamljanje in zdrsnitve še nekonsolidiranega apnenčevega dna. Potresni sunki so bili najbolj pogosti in močni prav na robu platforme, ki se je ob strmih prelomih prevešala v južneje ležeči Slovenski bazen. Da je bil ta del karbonatne platforme najbolj izpostavljen tektonskim učinkom, nam pričajo v kasnejšem obdobju (zgornji lias) na njem nastale globoke tenzijske prelomne in široko razprte razpoke, ki so jih zapolnile breče z rdečim vezivom v obliki neptunskih dajkov. Prav ti fenomeni pa so prostorsko vezani na širše območje Krna, kjer dobimo številne plasti tempestitov.

\section{Sklep}

Po litološkem razvoju in po mikrofaciesu lahko sklepamo, da se je noriško-retijski dachsteinski apnenec Krna odlagal v zelo plitvem morju. Strukturni tipi apnenca kažejo, da so se stalno menjavali v nad- in podplimskimi razmerami sedimentacije. Za nad- in medplimsko okolje so značične stromatolitne plasti, izsušitvene pore (loferit) in nadplimski konglomerat. Po klasifikaciji standardnega mikrofaciesa (SMF) in klasifikaciji sedimentacijskih okolij (FB - facies belt, Wils on, 1975; Flüg el, 1978) uvrščamo dolomitizirani stromatolitni in loferitni apnenec medplimskega okolja $\mathrm{V}$ 
SMF 19 in 20 ter v FB 8 do 9 (zaprta platforma in litoralni evaporiti). Glavnina apnenca se je odlagala v zelo plitvi vodi, ki ni bila globlja od 10 ali 20 metrov. Energijski indeks preiskanih vzorcev je nizek do zelo nizek, tako da lahko sklepamo na mirne sedimentacijske okoliščine, na zatišni del karbonatne platforme z lokalnimi lagunami. Apnenci podplimskega okolja kažejo znake standardnega mikrofaciesa (SMF) 8,9,13 in 18 (biomikrit, biosparit, onkoidni grainstone, foraminiferni in algni apnenec) ter pripadajo okolju odprte do delno zaprte karbonatne platforme (FB 7 in 9). Naštete značilnosti in monotoni razvoj dachsteinskega apnenca na obsežnem ozemlju Alp ter njegova velika debelina kažejo na to, da je bil paleorelief precej raven. Karbonatna platforma se je pogrezala zelo počasi, uravnoteženo s pogrezanjem pa je napredovala tudi sedimentacija. Večkrat je apnenec lokalno okopnel in bil izpostavljen paleozakrasovanju, na kar nas opozarjajo številne korozijske votline, zapolnjene s sparitnim kalcitom (sigo) in s karbonatno residualno glino.

Podoben razvoj dachsteinskega apnenca s številnimi ciklotemami, kakršen je na Krnu, poznamo iz širšega prostora zahodne Slovenije, posebno iz Julijskih Alp, npr. s Kaninskega pogorja, Trente (Jurkovšek, 1987; J urkovšek et al., 1990), Pokljuke in Kobariškega Stola (Bus er, 1986, 1987), Polovnika (Kušč er et al., 1974) ter iz Trnovskega gozda in roba Banjške planote (Ogorelec, 1975, 1988; O g orelec \& Rothe, 1993).

Za celotni omenjeni prostor je značilno, da kaže dachsteinski apnenec vse elemente klasičnega loferskega razvoja, značilno zanj pa je, da v teh cikotemah prevladujeta člena $\mathrm{B}$ in $\mathrm{C}$, medtem ko so bazalne breče $\mathrm{z}$ residualno glino (člen A) zelo redke.

Izredno pogostne korozijske votline so nastale na skrajnem južnem delu Julijske karbonatne platforme, ki je bil najbolj izpostavljen dolgotrajnim okopnitvam oziroma vsaj pogosteje kakor severno ležeče lagunsko območje. Ker se te votline pojavljajo samo v apnencu člena C loferske cikloteme, ne pa tudi v členu B (stromatolitne plasti), je verjetno vzrok, da zgodnjediagenetsko dolomatizirane stromatolitne plasti niso bile tako intenzivno zakrasele kakor apnenčeve. Nastanek tempestitov povezujemo s pogostnimi potresnimi sunki, ki so prelamljali še nekonsolidirane apnenčeve plasti, katere so zdrsnile ena ob drugi. Do najintenzivnejših potresnih sunkov je prihajalo prav na meji Julijske karbonatne platforme in južneje ležečega Slovenskega bazena, kjer so nastali dachsteinski apnenci posnetega profila. 


\section{References}

Aigner, T. 1982: Calcareous tempestites: storm - dominated stratification, Upper Muschelkalk limestones (Middle Trias, SW Germany). In: G. Einsele \& E. Seil a cher (eds.) - Cyclic and Event Stratification, 180-198, Springer Verl., Berlin.

A itken, J. D. 1967: Classification and environmental significance of cryptalgal limestones and dolomites with illustrations from the Cambrian and Ordovician of southwestern Alberta. Jour. Sed. Petrol. 37, 1163-1178, Tulsa.

Assereto, R. L. \& Kendall, C. G. St. C. 1977: Nature, origin and classification of peritidal tepee structures and related breccias. - Sedimentology, 24/2, 153-210, Oxford.

B a bi ć, Lj. 1968: O triasu Gorskog kotara i susjednih područja. - Geol. vjesnik, 21, 11-18, Zagreb.

B a bić, Lj. 1980/81: The prigin of "Krn breccia" and the role of the Krn area in the Upper Triassic and Jurassic history of the Julian Alps. - Vesnik Zavoda za geol. i geof. istraž. A-Geologija, 38/39, (1980/81) 59-88, Beograd.

Bernouilli, D. \& Jenkyns, H. C. 1974: Alpine, Mediterranean, and Central Atlantic Mesozoic facies in relation to the early evolution of the Tethys. -In: R. H. D o tt \& R. H. S haver (eds.) - Modern and Ancient Geosynclinal Sedimentation. SEPM Spec. Publ. 19, 129-160, Tulsa.

B os ellini, A. 1967: La tematica deposizionale della Dolomia Principale (Dolomiti e Prealpi Venente). Boll. Soc. Geol. It., 68/2, 133-169, Roma.

Bosellini, A. \& Rossi, D. 1974: Triassic carbonate buildups of the Dolomites, Northern Italy. In: I. F. La p or te (ed.) - Reefs in time and space. - SEPM Spec. Publ., 18, 209-233, Tulsa.

Bus er, S. 1974: Tolmač lista Ribnica, Osnovna geološka karta SFRJ 1:100.000. - Zvezni geol. zavod, 60 p., Beograd.

Buser, S. 1986: Tolmač listov Tolmin in Videm (Udine), Osnovna geološka karta SFRJ 1:100.000. - Zvezni geol. zavod, 103 p., Beograd.

Buser, S. 1987: Osnovna geološka karta SFRJ, list Tolmin in Videm 1:100.000. - Geološki zavod Ljubljana.

Buser, S. 1989: Development of the Dinaric and the Julian carbonate platforms and of the intermediate Slovenian basin (NW Yugoslavia). - Mem. Soc. Geol. Ital., 40 (1987), 313-320, Roma.

Buser, S. \& Debeljak, I. 1996: Lower Jurassic beds with bivalves in south Slovenia. Geologija 37, 38, (1994/95), 23-62, Ljubljana.

Catalano, R., D'Argenio, B. \& Lo Cicero, G. 1974: I ciclotemi triassici di Capo Rama (Monti di Palermo). - Geologica Romana, 13, 125-145, Roma.

Č a dj en ovi ć, D. 1988: Lofer-Facija. - Vodič ekskurzije, 6. Skup sedimentologa Jugoslavije, Crnogorsko geol. društvo, 10-16, Titograd.

Dimitrijević, M. N. \& Dimitrijević, M. D. 1988: Ekskurzija Cetinje-Bečići-Stari Bar Tačka $C_{2}$ - Stari Bar, Vrela Rijeka. - Vodič ekskurzije, 6. Skup sedimentologa Jugoslavije, Crnogorsko geološko društvo, 17-18, Titograd.

Do zet, S. 1990: Loferske cikloteme v glavnem dolomitu Kočevske. - Rud.-met. zbornik, 4, 507-528, Ljubljana.

F is cher, A. G. 1964: The Lofer cyclothems of the Alpine Triassic. In : D. F. Meeria m (ed.) - Symposium on cyclic sedimentation. - Kansas Geol. Soc. Bull., 169/1, 107-150, Lawrence.

Fis cher, A. G. 1975: Tidal deposits, Dachstein limestone of the North Alpine Triassic. - In: R. N. G in s burg (ed.) - Tidal Deposits. Springer Verlag, 235-242, Berlin.

Flüg el, E. 1963: Zur Mikrofazies des Alpinen Trias. - Jb. Geol. B. A., 106, 205-228, Wien.

Flüg el, E. 1972: Mikrofazielle Untersuchungen in der Alpinen Trias, Methoden und Probleme. - Mitt. Ges. Geol. Bergbaustud., 21, 9-64, Innsbruck.

Flüg el, E. 1978: Mikrofazielle Untersuchungsmethoden von Kalken. - Springer Verlag, 454 p., Berlin.

F ülö p, J. 1976: The Mesozoic Basement Horst Blocks of Tata. - Geol. Hungarica, 16, Inst. Geol. Hung., 228 p., Budapest.

Gebelein, C. D. 1969: Distribution, morphology and accretion rate of Recent subtidal algal stromatolites, Bermuda. - Jour. Sed. Petrol, 39/1, 49-69, Tulsa.

Gebelein, C. D. \& Hoffman, P. 1973: Algal origin of dolomite laminations in stromatolitic limestone. - Jour. Sed. Petrol., 43, 603-613, Tulsa.

Ha as, J. 1994: Lofer cycles of the Upper Triassic Dachstein-Platform in the TDMN, Hungary. - Spec.Publ. Int. Ass. Sedim., 19, 303-322, Oxford.

Herak, M., Sokač, B. \& Ščavničar, B. 1967: Correlation of the Triassic in SW Lika, Paklenica and Gorski Kotar (Croatia). - Geol. zbornik, 18/2, 189-202, Bratislava.

Illing. L. V., Wells, A. J. \& Ta ylor, J. C. M. 1965: Penecontemporary dolomite in the Persian Gulf. In: L. C.Pray \& R. C. Murray (eds.) - Dolomitization and limestone diagenesis, a symposium. SEPM Spec. Publ., 13, 89-111, Tulsa. 
Jurkovšek, B. 1987: Osnovna geološka karta SFRJ, list Beljak in Ponteba 1:100.000. Geološki zavod Ljubljana.

Jurkovšek, B., Šribar, L., Ogorelec, B. \& Kolar - Jurkovšek, T. 1990: Pelagične jurske in kredne plasti v zahodnem delu Julijskih Alp. - Geologija, 31/32, 285-328, Ljubljana.

Kušč er, D., Grad, K., N os an, A. \& O g or ele c, B. 1974: Geološke raziskave soške doline med Bovcem in Kobaridom. - Geologija, 17, 425-476, Ljubljana.

Matavelli, L., Chilingarian, G. V. \& Storer, D. 1969: Petrography and diagenesis of the Taormina formation, Gela oil field, Sicily (Italy). -Sedimentary Geology, 3, 59-86, Amsterdam.

Ogorelec, B. 1975: Mikrofacielne, mineraloške in geokemične značilnosti dachsteinskega apnenca na območju Trnovskega gozda in Banjške planote. - Mezozoik v Sloveniji. I. faza, Arhiv GZL in FNT Ljubljana, 31 p., Ljubljana.

Ogorelec, B. 1988: Mikrofazies, Geochemie und Diagenese des Dachsteinkalkes und Hauptdolomits in Süd-West-Slowenien, Jugoslawien. - Dissertation, Univ. Heidelberg, 173 p., Heidelberg.

Ogorelec, B. \& Rothe, P. 1993: Mikrofazies, Diagenese und Geochemie des Dachsteinkalkes und Hauptdolomits in Süd-West-Slowenien. - Geologija, 35, (1992) 81-181, Ljubljana.

S ander. B. 1936: Beiträge zur Kenntnis der Anlagerungsgefüge (Rhytmische Kalke und Dolomite aus Tirol). - Tschermaksć Mineral. Petrogr. Mitt., 46, 27-209, Wien.

Selli, R. 1963: Shema geologica delle Alpi Carniche e Giulie Occidentali. Anali Museo Geol. Bologna, Ser. 2, 30, 136 p.p. Bologna.

Turnšek, D. \& Buser, S. 1991: Norian-Rhaetian coral reef buildups in Bohinj and Rdeči rob in southern Julian Alps (Slovenia). - Razprave SAZU, IV. razr., 32/7, 215-257, Ljubljana.

$\mathrm{Z}$ an k1, H. 1967: Die Karbonatsedimente der Obertrias in den nördlichen Kalkalpen. - Geol. Rundschau, 56, 128-139, Stuttgart.

Zank1, H. 1971: Upper Triassic carbonate facies in the Northern Limestone Alps. In: G. Müller (ed). Sedimentology of Parts of Central Europe, Guidebook. - 8. Int. Sediment. Congress 1971, 147-185, Heidelberg.

Wils o n, J. L. 1975: Carbonate Facies in Geologic History. - Springer Verl., 471 p., Berlin. 


\section{Plate 1 - Tabla 1}

1 Intramicritic limestone with shrinkage pores cemented by sparry calcite (loferite) $\operatorname{Krn} 8, \times 30$ Intramikritni apnenec z izsušitvenimi porami, zapolnjenimi s sparitnim kalcitom (loferit) Krn $8, \times 30$

2 Micritic limestone with numerous shrinkage pores and sheet cracks; member B of the Lofer cyclothem

Krn 2B, $\times 30$

Mikritni apnenec s številnimi drobnimi izsušitvenimi porami in razpokami; člen B loferske cikloteme

$\mathrm{Krn} 2 \mathrm{~B}, \times 30$

3 Skeletal alga Solenopora sp. in washed intramicritic limestone Krn $14, \times 30$

Odlomek skeletne alge Solenopora sp. v izpranem intramikritnem apnencu $\operatorname{Krn} 14, \times 30$ 

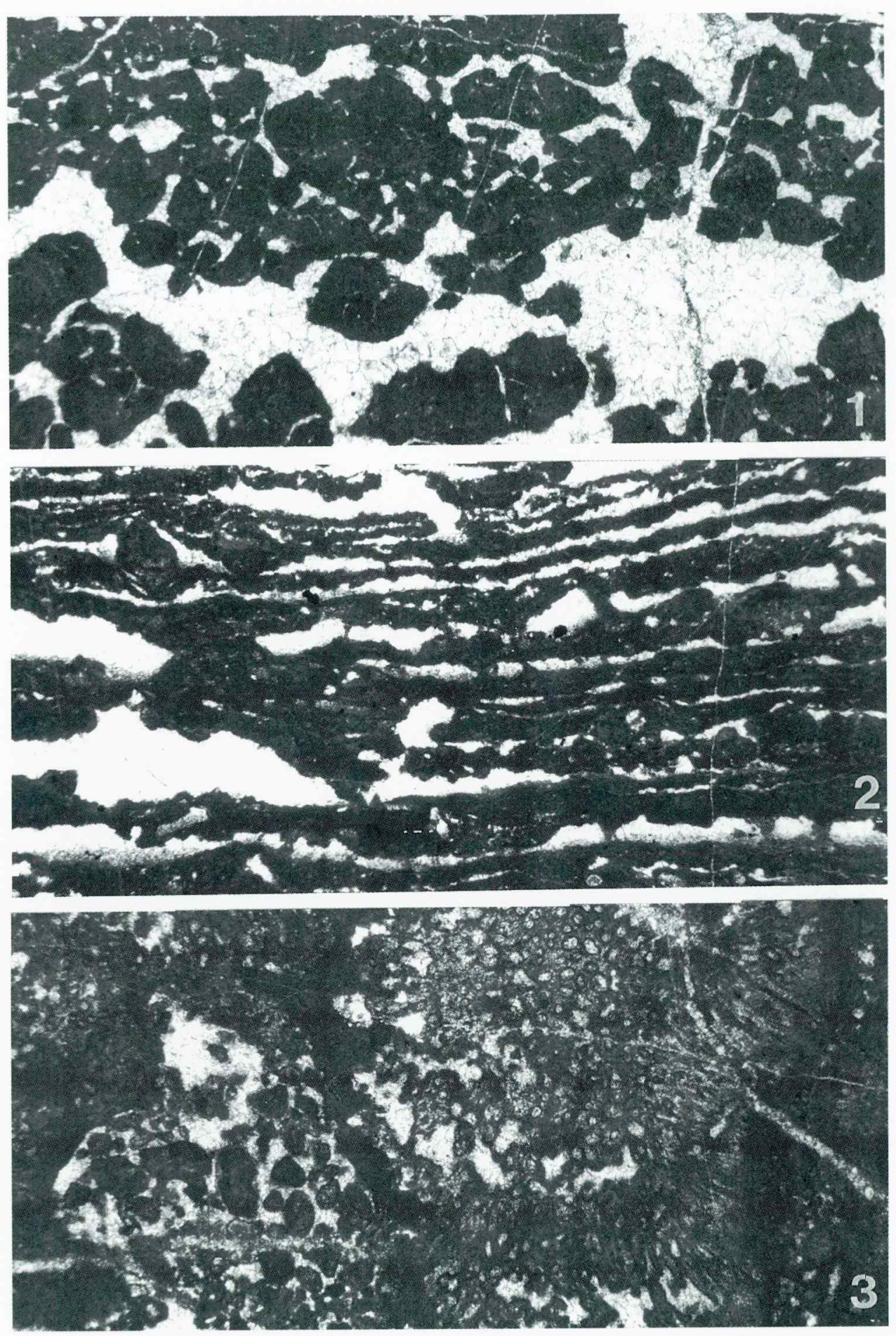
Plate 2 - Tabla 2

1 Detail of dolomitized stromatolitic limestone

Krn $12, \times 15$

Detajl dolomitiziranega stromatolitnega apnenca

Krn $12, \times 15$

2 Loferite; shrinkage pores are infilled with internal micritic silt; geopetal structure Krn 2A, x 40

Loferit; izsušitvene pore geopetalno zapolnjuje interni mikrit

$\operatorname{Krn} 2 \mathrm{~A}, \times 40$

3 Pelmicritic limestone (loferite) - a detail. Stalactitic cement at the roof of a shrinkage pore (arrows) indicating meteoric diagenetic conditions

$\operatorname{Krn} 5, \times 40$

Pelmikritni apnenec (loferit) - detajl. V vrhnjem delu pore opazujemo stalaktitni cement (puščice), ki kaže na diagenezo v meteorskih razmerah

Krn $5, \times 40$

4 A detail of smaller solution cavity in washed pelmicritic limestone. Radiaxial fibrous calcite, dog-tooth granular cement (arrows) and internal silt with red residual clay

Krn $18, \times 15$

Detajl manjše korozijske votline v izpranem pelmikritnem apnencu. Vlaknati kalcit s conarno strukturo, zrnati sparit (puščici) ter interni sediment rdeče residualne gline zapolnjujejo votlino

Krn 18, x 15 

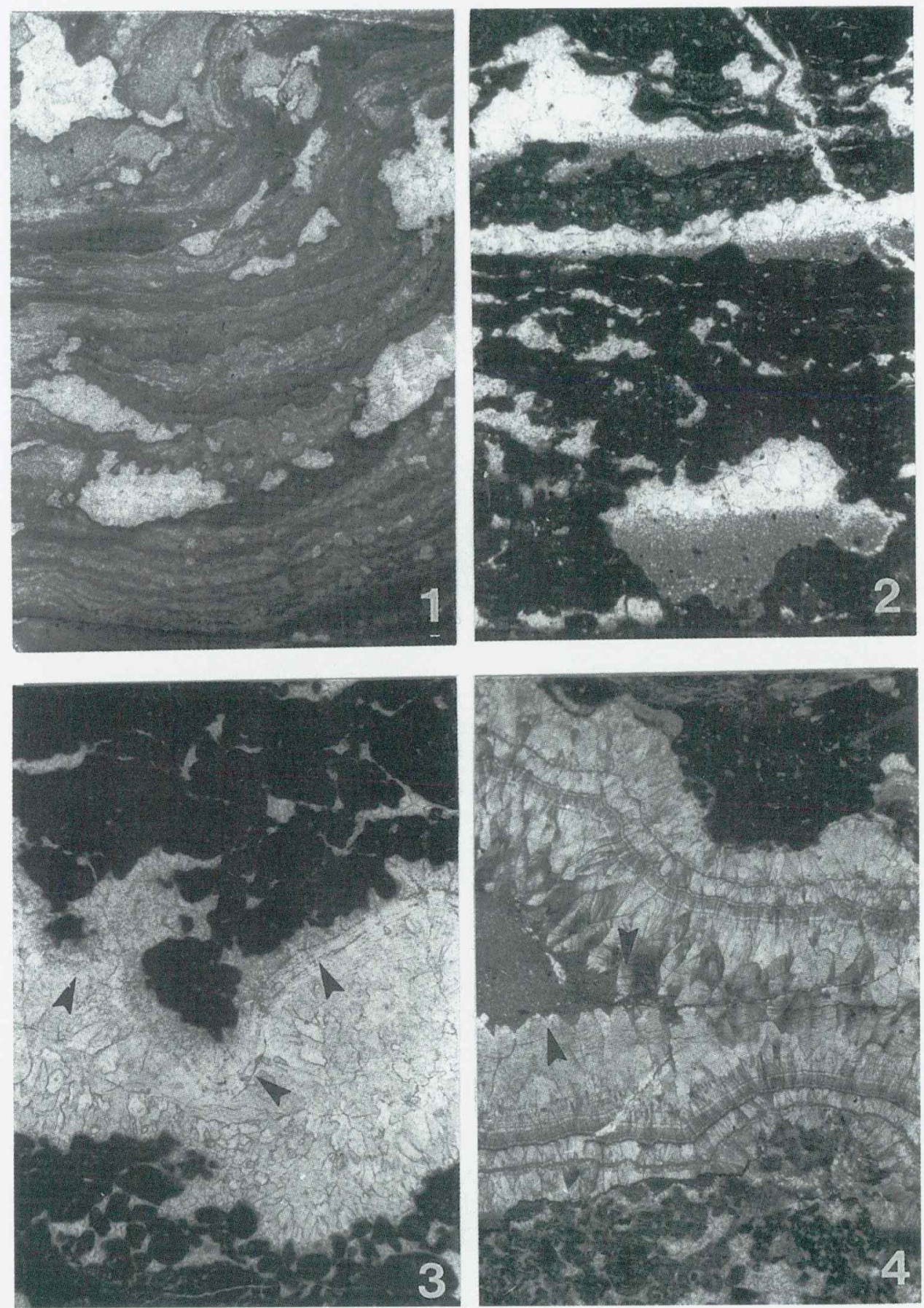


\section{Plate 3 - Tabla 3}

1 Spongeous stromatolitic structure with shrinkage pores $\operatorname{Krn} 22, \times 10$

Stromatolitna kopuča, prepredena $z$ izsušitvenimi porami $\operatorname{Krn} 22, \times 10$

2 Oncoids in washed pelmicritic limestone with shrinkage pores Krn $3 \mathrm{~A}, \times 10$

Onkoidi v izpranem pelmikritnem apnencu z izsušitvenimi porami Krn $3 \mathrm{~A}, \times 10$

3 Vadose pisoids, encrusted with stromatolitic envelopes Krn 28, × 10

Vadozni pisoidi, ki jih preraščajo stromatolitne skorje Krn 28, × 10 

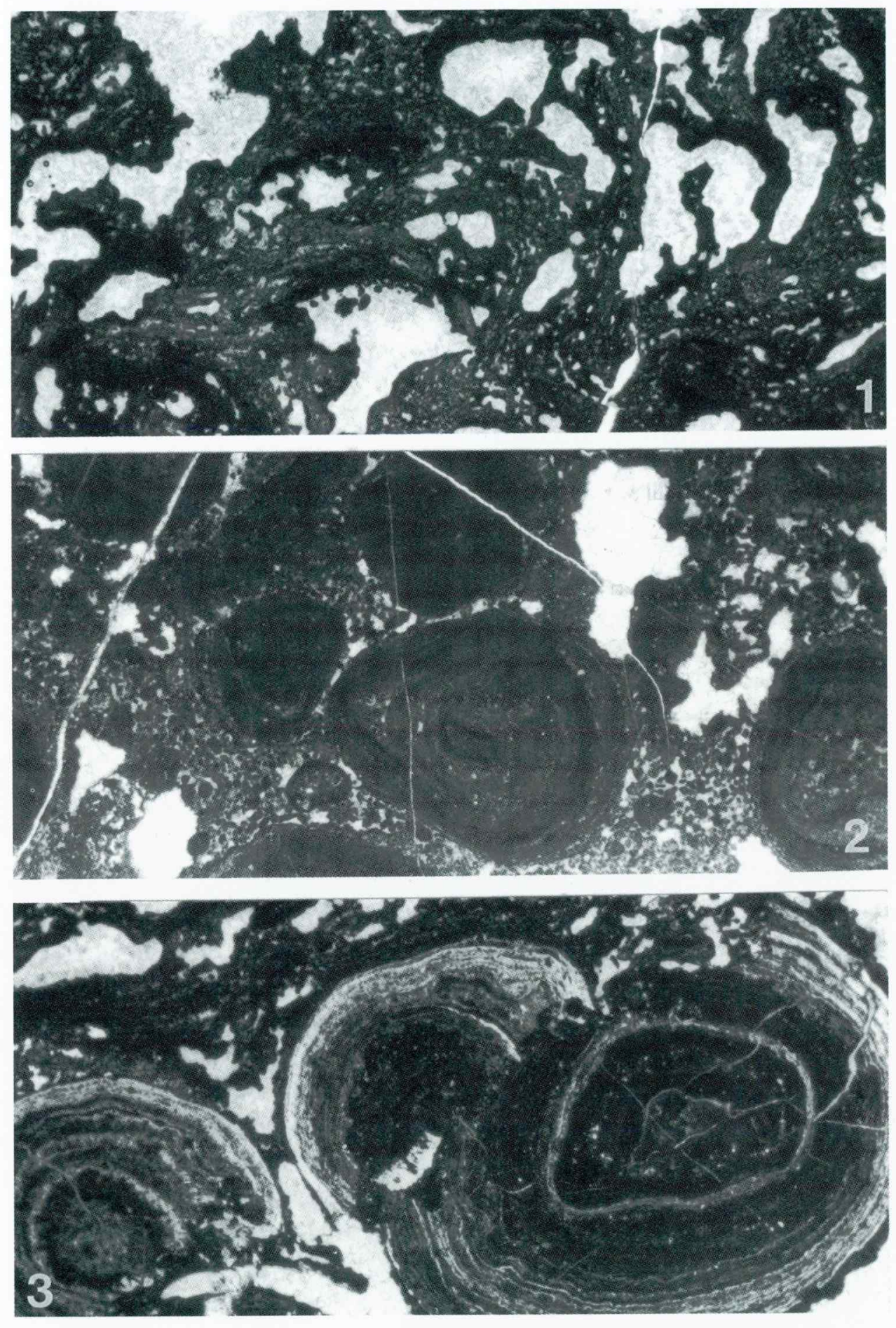